\title{
EVALUATION OF GROUNDWATER AQUIFER IN THE AREA BETWEEN EL-QUSIYA AND MANFALUT USING VERTICAL ELECTRIC SOUNDINGS (VES) TECHNIQUE
}

\author{
Waleed S.S. ${ }^{1}$, Abd El-Monaim, A, E. ${ }^{2}$, Mansour M.M. ${ }^{3}$ \\ and El-Karamany M. F. \\ ${ }^{1}$ Ministry of Water Resources (underground water sector) \\ ${ }^{2}$ Research Institute for Groundwater \\ ${ }^{3}$ Mining \& Met. Dept., Faculty of Eng., Assiut University
}

(Received August 5, 2009 Accepted August 17, 2009).

The studied area is located northwest of Assiut city which represents a large part of the Nile Valley in Assiut governorate. It lies between latitudes $27^{\circ} 15^{\prime} 00^{\prime \prime}$ and $27^{\circ} 27^{\prime} 00^{\prime \prime} \mathrm{N}$, and longitudes $30^{\circ} 42^{\prime} 30^{\prime \prime}$ to $31^{\circ}$ $00^{\prime}$ E, covering approximately 330 square kilometers. Fifteen Vertical Electrical soundings (VES) were carried out to evaluate the aquifer in the study area. These soundings were arranged to construct three geoelectric profiles crossing the Nile Valley. Three cross sections were constructed along these profiles to detect the geometry and geoelectric characteristics of the quaternary aquifer based on the interpretation of the sounding curves and the comparison with available drilled wells. The interpretation showed that the thickness of the quaternary aquifer in the study area ranges between 75 and $300 \mathrm{~m}$, in which the maximum thicknesses are detected around Manfalut and at the west of El-Qusiya.

\section{INTRODUCTION}

During the two last decades, there is a continuous demand for big amount of water necessary for the land expansion projects in Egypt. So, the development of groundwater resources receives special attention, since the groundwater reservoir underlying the Nile Valley and its adjacent desert areas acting as auxiliary source of water in Egypt. These resources have great advantages due to the flexibility and low coasts of production as well as their high reliability during emergencies.

Accordingly, the main scope of the present study is to assess and evaluate the characteristics of the quaternary aquifer in the area covering the region in Upper Egypt, extending between Manfalut and El-Qussiyah, in Assiut governorate as shown in Figure (1).

\section{GENERAL GEOLOGY}

Different geological and geophysical studies were carried out by many authors as Bishay (1961)[1], Said (1962)[2], El-Gamili (1964)[3], Shama (1972)[4], Bassiouni et al. (1974)[5], Youssef et al. (1977)[6], Said (1981)[7], Nakhla et al. (1986)[8], CONOCO (1987)[9], Rizkalla (1989)[10], Said (1990)[11], Abd El-Monaim. (1994)[12], Eman (2004)[13], EL Tahlawi et al. (2007)[14] and many others. 
The rocks cropping out in the study area are of sedimentary origin, and belong to Lower Eocene to Quaternary (Fig. 2-a, and 2-b). The Lower Eocene, carbonate rocks are represented by the plateaux bordering the Nile Valley and cover a large part of the study area. In the subsurface, the Lower Eocene rock to the bottom of the Nile Valley. The Nile gorge is filled with the Pliocene and Quaternary deposits. The Pliocene deposits consist of clay with some interbeds of sand, and are unconformably resting on the Eocene carbonate.

The Quaternary deposits are composed of sand and gravel and are generally capped by silty clay layers.

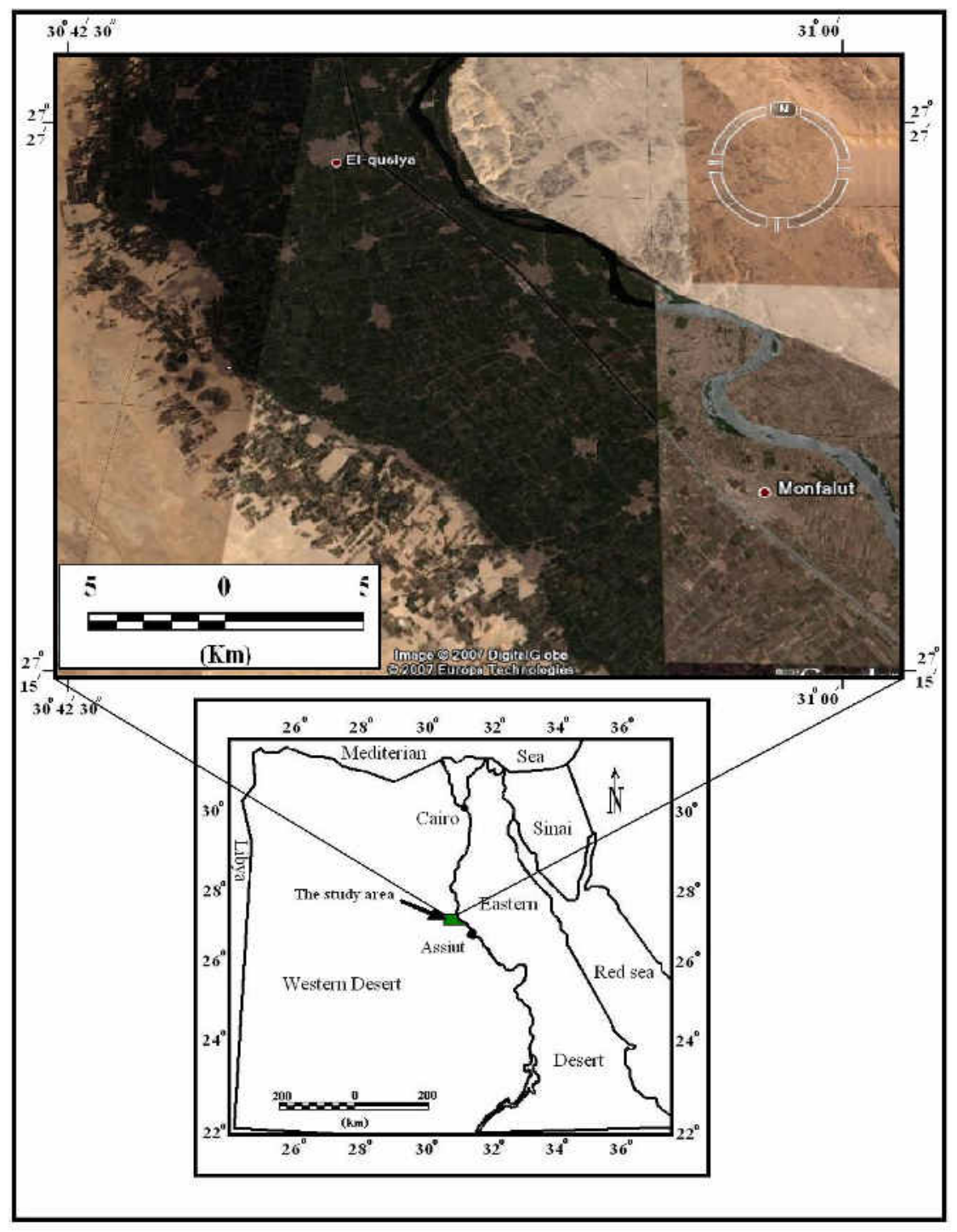

Fig.(1): Location map of the study area 


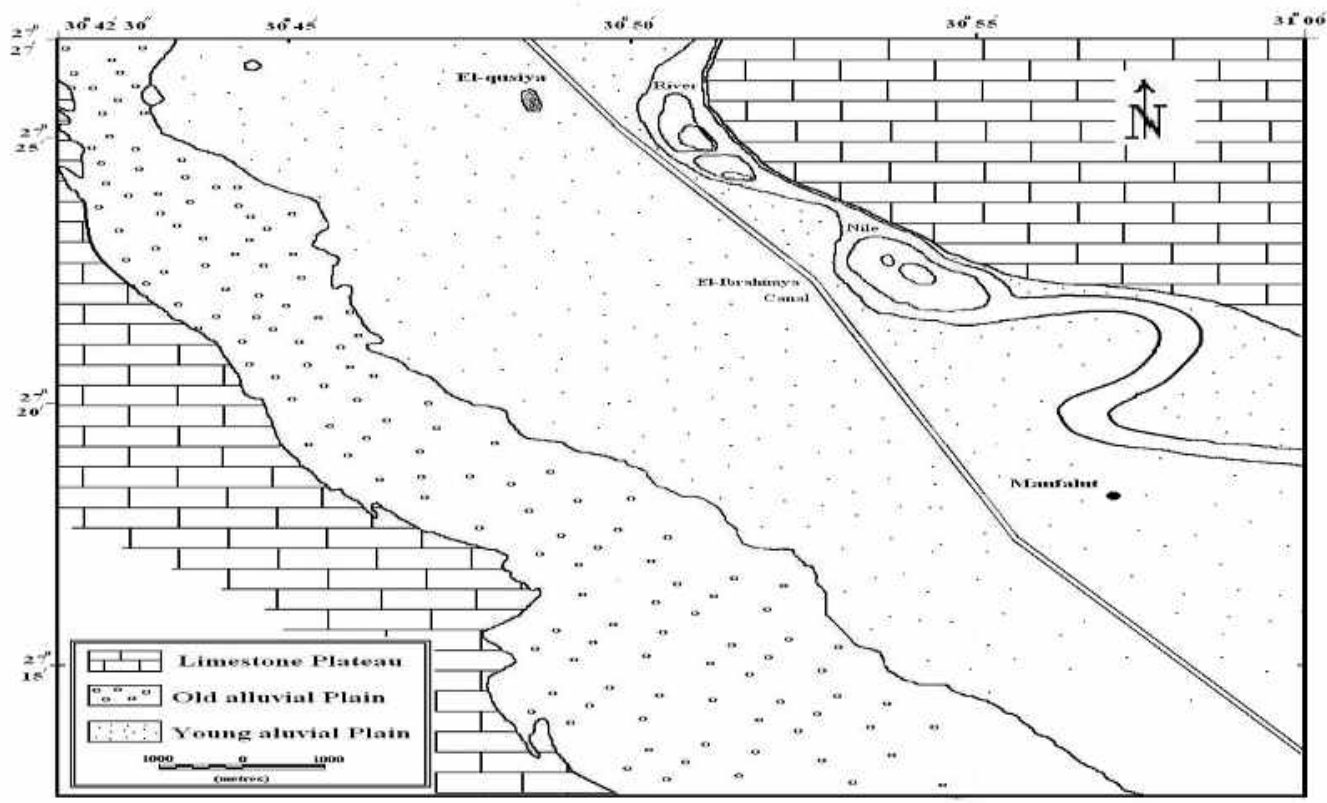

Fig. ( 2-a ): Geomorphological map of the study area.

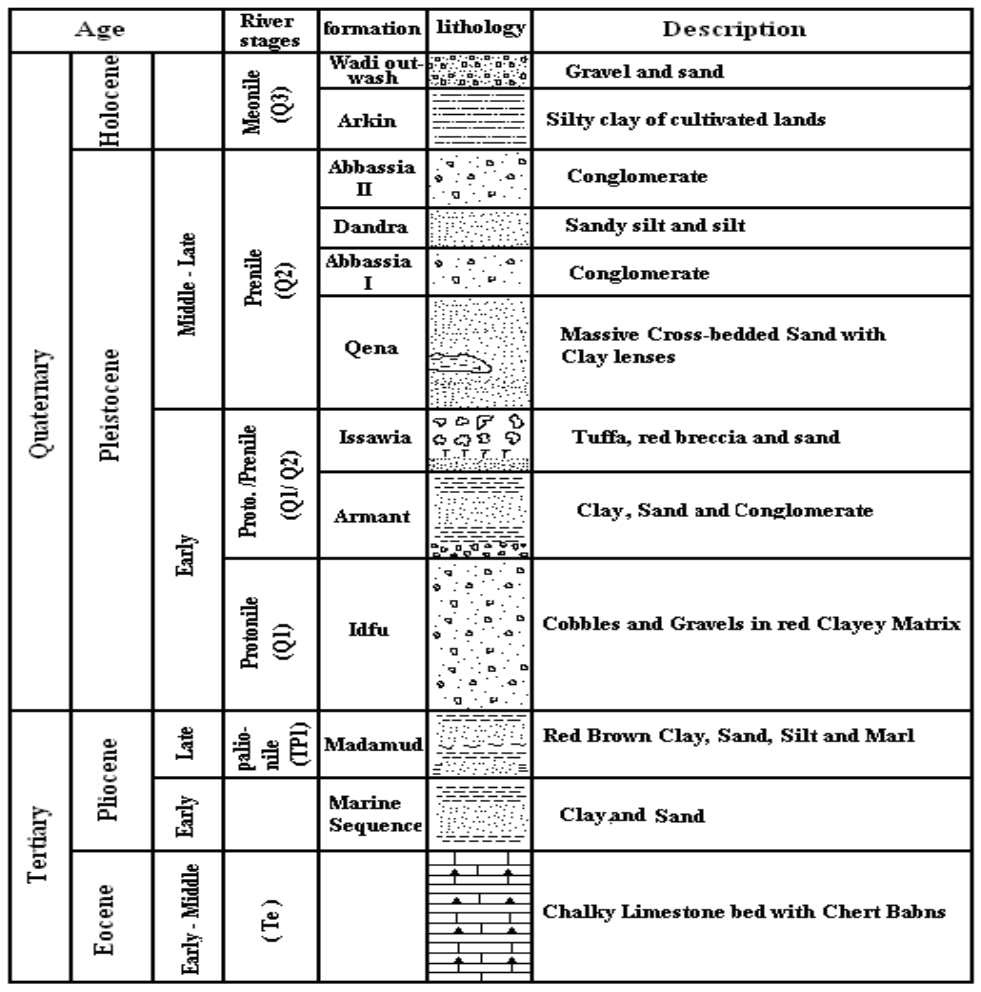

Fig. (2-b ): Composite Stratigraphic Section In The Study Area (Said, 1981 and 1990). 


\section{FIELD TECHNIQUE}

In the present study, the Terrameter SAS 300 and Syscal R1 (Fig. 3) are used for conducting the geoelectric field survey. Some necessary accessories such as batteries, calibrating resistors for checking the instrument, steel electrodes of about $0.85 \mathrm{~m}$ in length and $2.5 \mathrm{~cm}$ in diameter, cables, hammers, Brunton compass, wood marks, GPS instrument, and wireless telephone are also used.

The instrument permits natural or induced signals to be measured at extremely low levels, with excellent penetration and low power consumption. Moreover, it can be used in a wide variety of applications where effective signal/noise discrimination is needed.

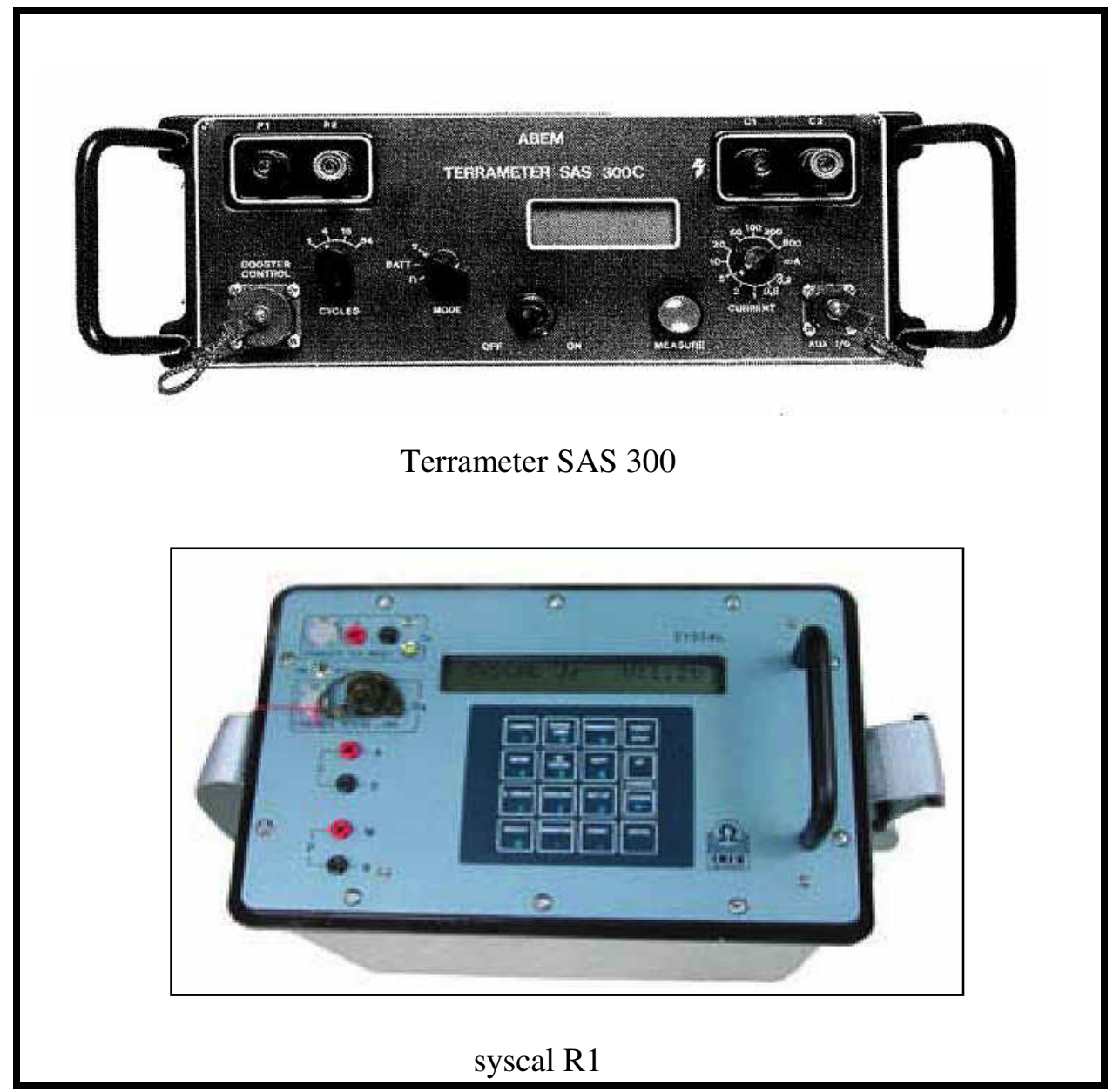

Fig. (3) Earth resistivity meter instrument Terrameter SAS 300 and syscal R1 plus used for the electrical filed survey. 
The electrical resistivity survey in the studied area comprises fifteen VES covered the studied area (Fig.4) using schlumberger electrode configuration. Distance between current electrodes $(\mathrm{AB} / 2)$ varied from $1.5 \mathrm{~m}$ to $1000 \mathrm{~m}$, according to the topography of the station location.

A quantitative interpretation process for the measured field curves, have been carried by a computer program RES1D ver. 1.0 (M. H. Loke, 2001)[15] for both Inversion and forward modeling.

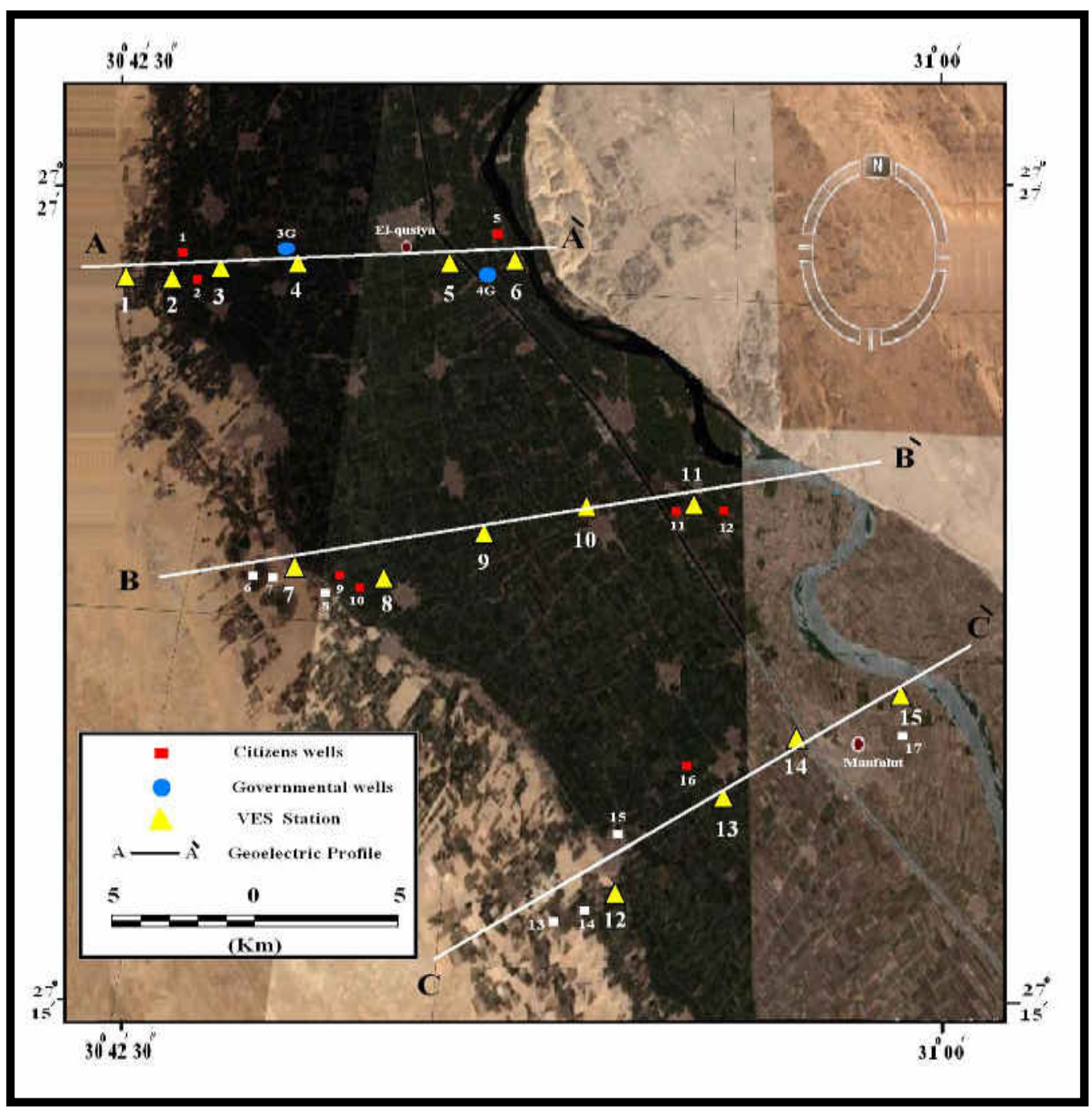

Fig. (4): Location map of the vertical electrical sounding stations and drilled bore holes in the study area 


\section{INTERPRETATION AND DISCUSSION OF RESULTS}

In the studied area, fifteen vertical electrical soundings were carried using Schlumberger electrode configuration. The interpretation of the sounding curves was carried out through four steps:

1- Smoothing of the field curves by neglecting of the sharp peaks that may be occurred due to intermediate layers of small thickness (less than one meter).

2- Introducing the smoothed curves to automatic interpretation using the software of RES1D Ver. 1.0 prepared by Loke M.H. (2001)

3- Prepare a layers model from the outputs of steps (2) by summing up the layers that have equal or nearer resistivity values.

4- Introducing the layers model resulting from step (3) into the RES1D program. Much iteration were used to reach the best fit between the observed (smoothed) field values and the calculated values (Fig. 5) The final results from steps (3) and (4) applied for the fifteen VESes are given in table (1).

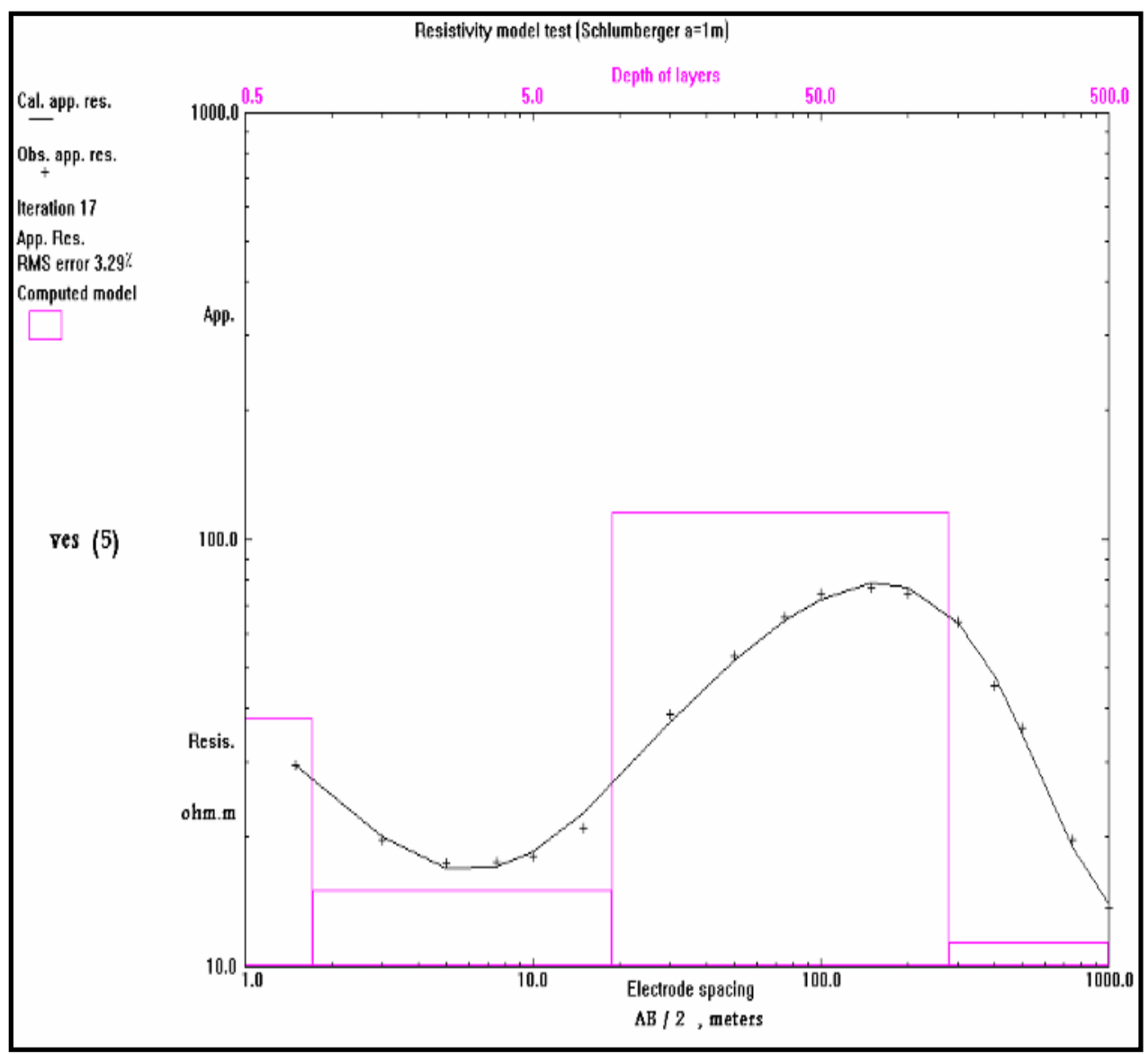

Fig. (5): Resistivity model test for VES No.5 using RES1D program. 
Table (1): Interpretation of results of VES curves in the studied area using RES1D (2001) Program.

\begin{tabular}{|c|c|c|c|c|c|c|c|c|c|c|c|}
\hline $\begin{array}{c}\text { VES } \\
\text { No. }\end{array}$ & \multicolumn{5}{|c|}{ Thickness of layer (m) } & \multicolumn{3}{c|}{ Apparent True Resistivity of layer (ohm.m) } \\
\hline & No.1 & No.2 & No.3 & No.4 & & No.1 & No.2 & No.3 & No.4 & No.5 & No.6 \\
\hline S-1 & 0.54 & 9.982 & 18.96 & 210.3 & --- & 560.28 & 66.02 & 23.52 & 15.502 & 0.095 & --- \\
\hline S-2 & 1.75 & 153.5 & 102.7 & --- & --- & 189.06 & 22.20 & 0.152 & 9.429 & --- & --- \\
\hline S-3 & 4.98 & 187.8 & --- & ---- & --- & 22.938 & 44.73 & 4.488 & --- & --- & --- \\
\hline S-4 & 2.39 & 7.220 & 275.7 & ---- & --- & 14.427 & 5.024 & 45.94 & 1.129 & --- & --- \\
\hline S-5 & 0.86 & 8.530 & 130.2 & --- & --- & 38.198 & 15.05 & 115.5 & 11.383 & --- & --- \\
\hline S-6 & 6.10 & 7.704 & 53.55 & 322.2 & --- & 34.100 & 35.17 & 55.86 & 6.044 & 35.08 & --- \\
\hline S-7 & 2.40 & 10.48 & 72.63 & 146.9 & --- & 204.64 & 15.80 & 33.71 & 17.346 & 1.614 & --- \\
\hline S-8 & 4.87 & 2.028 & 6.392 & 211.0 & --- & 45.730 & 2.193 & 121.3 & 25.398 & 1.876 & --- \\
\hline S-9 & 13.1 & 85.09 & 138.7 & --- & --- & 6.346 & 43.76 & 126.9 & 3.469 & --- & --- \\
\hline S-10 & 8.33 & 241.3 & 162.3 & 134.2 & --- & 7.508 & 29.88 & 9.959 & 6.002 & 0.757 & --- \\
\hline S-11 & 0.56 & 72.97 & 59.45 & --- & --- & 3.361 & 29.46 & 79.96 & 3.445 & --- & --- \\
\hline S-12 & 0.73 & 3.538 & 24.11 & 32.74 & 59.8 & 10432 & 174.7 & 40.28 & 15.848 & 87.94 & 4.3 \\
\hline S-13 & 1.96 & 1.975 & 287.1 & --- & --- & 5.179 & 2.710 & 61.75 & 2.120 & --- & --- \\
\hline S-14 & 7.69 & 31.98 & 266.7 & --- & --- & 6.632 & 342.8 & 60.81 & 25.514 & --- & --- \\
\hline S-15 & 0.72 & 13.94 & 128.2 & 58.78 & --- & 15.599 & 196.2 & 50.17 & 50.567 & 4.071 & --- \\
\hline
\end{tabular}

The comparison between the interpreted results from VESes No.4 \& 5 and the lithologic sequences of the neighboring wells drilled recently shows that there is a good agreement between the layers model from VESes and the actual lithology of the drilled wells No.3G \& 4G, (Fig.6). Accordingly, the following resistivity ranges are defined corresponding to the different sedimentary facies:

1- Geoelectrical layers that have resistivity from 5 to $22 \mathrm{ohm} . \mathrm{m}$ and encountered in the surface are corresponding to clay and silty deposits.

2- Geoelectrical layers that have resistivity from 15 to $120 \mathrm{ohm} . \mathrm{m}$. corresponding to the Quaternary aquifer.

3- Geoelectrical layers that have resistivity from 0.1 to $11 \mathrm{ohm} . \mathrm{m}$. corresponding to Pliocene clay.

Three geoelectrical sections A-A', B-B' and C-C' were constructed. Section AA' comprises six VESes, (Fig. 4) namely 1, 2, 3, 4, 5 and 6 with $14 \mathrm{~km}$ length. Section B-B' comprises five VESes, namely 7, 8, 9, 10 and 11 with $13 \mathrm{~km}$ length (Fig. 4). Section C-C' comprises four VESes, namely $12,13,14$ and 15 and has $11 \mathrm{~km}$ length (Fig. 4). Also, in this study, maps of the aquifer base and its thickness were constructed to display the variations of the aquifer thickness (Fig. 10\& 11). 


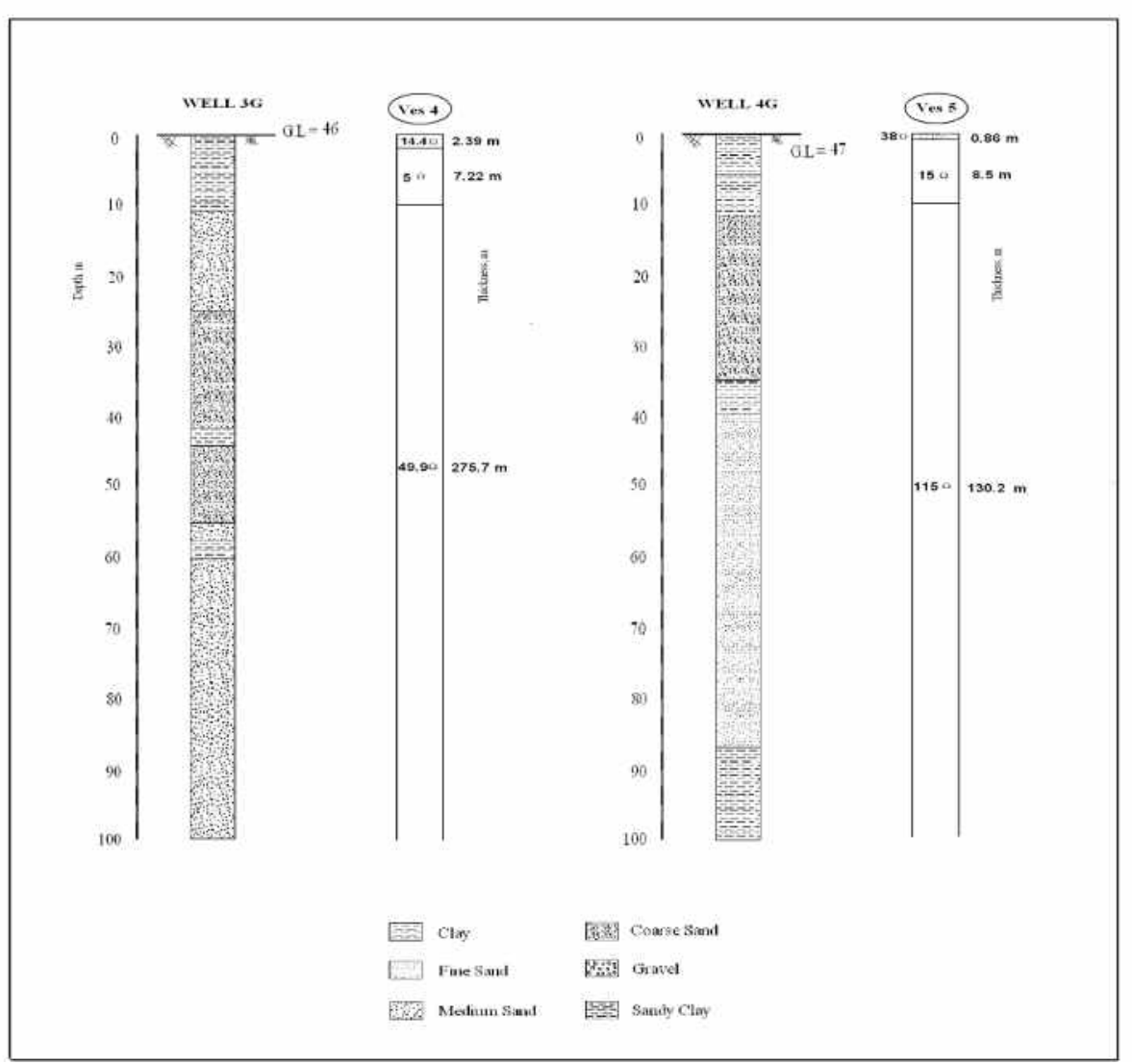

Fig. (6): Comparison between lithologic log of drilled wells No. 3G \& 4G and the interpretation of VESes No. $4 \& 5$ in the study area.

\section{Geoelectrical cross section a-a'}

This section runs through El-Qusiya town (Fig. 4). It is based on the results of soundings Nos. 1, 2, 3, 4, 5 and 6 . This section also passes through wells 1, 2, 3G, 4G and 5, 3G and 4G wells are drilled by (Ground Water Sector in the Ministry of Water Resources and Irrigation). The direction of the section is W-E with total length of about $14 \mathrm{~km}$.

The constructed section shows regular aquifer geometry. With the help of the bore holes, the section reflects the vertical variation in lithology and true resistivity values. Three geoelectrical units can be noticed in this section (Fig. 7) and described as follow:

(a) A superficial thin unit of clayey and silty deposits is characterized by low resistivity values (5-22 Ohm.m.). The thickness of this unit reaches its maximum value in bore hole No.5 to be $18 \mathrm{~m}$ and decreases gradually towards the East and West. This unit represents the clay-silt cap of the Quaternary aquifer, but it disappears in the fringes of the cultivated land near VES No.1, where dry sands with high resistivity appear. 
(b) A subsurface unit representing the Quaternary (Pleistocene) aquifer underlying the superficial unit. The formation is composed of sands, gravels with clay lenses with resistivity values ranging from 15 to $115 \mathrm{Ohm} . \mathrm{m}$ and this refer to the change in lithology. The maximum thickness of the aquifer is recorded near VES No. 4 (about $275 \mathrm{~m}$ ). The thickness of the aquifer decreases East and West. The difference in resistivity is due to the lithologic variations. At some places this unit may be covered by thin sheet of derived sand (VESNo.1 and VES No.2). The derived sand in this case is characterized by relatively higher electric resistivity values (100-500 Ohm.m.).

(c) A basal unit formed of Pliocene clay and characterized by its relatively low resistivity, ranging from 0.1 to $11 \mathrm{Ohm} . \mathrm{m}$ representing the base of the Quaternary aquifer and acts as aquiclude.

The section is bounded from both sides by Eocene limestone with high resistivity value reaching more than $130 \mathrm{Ohm} . \mathrm{m}$.

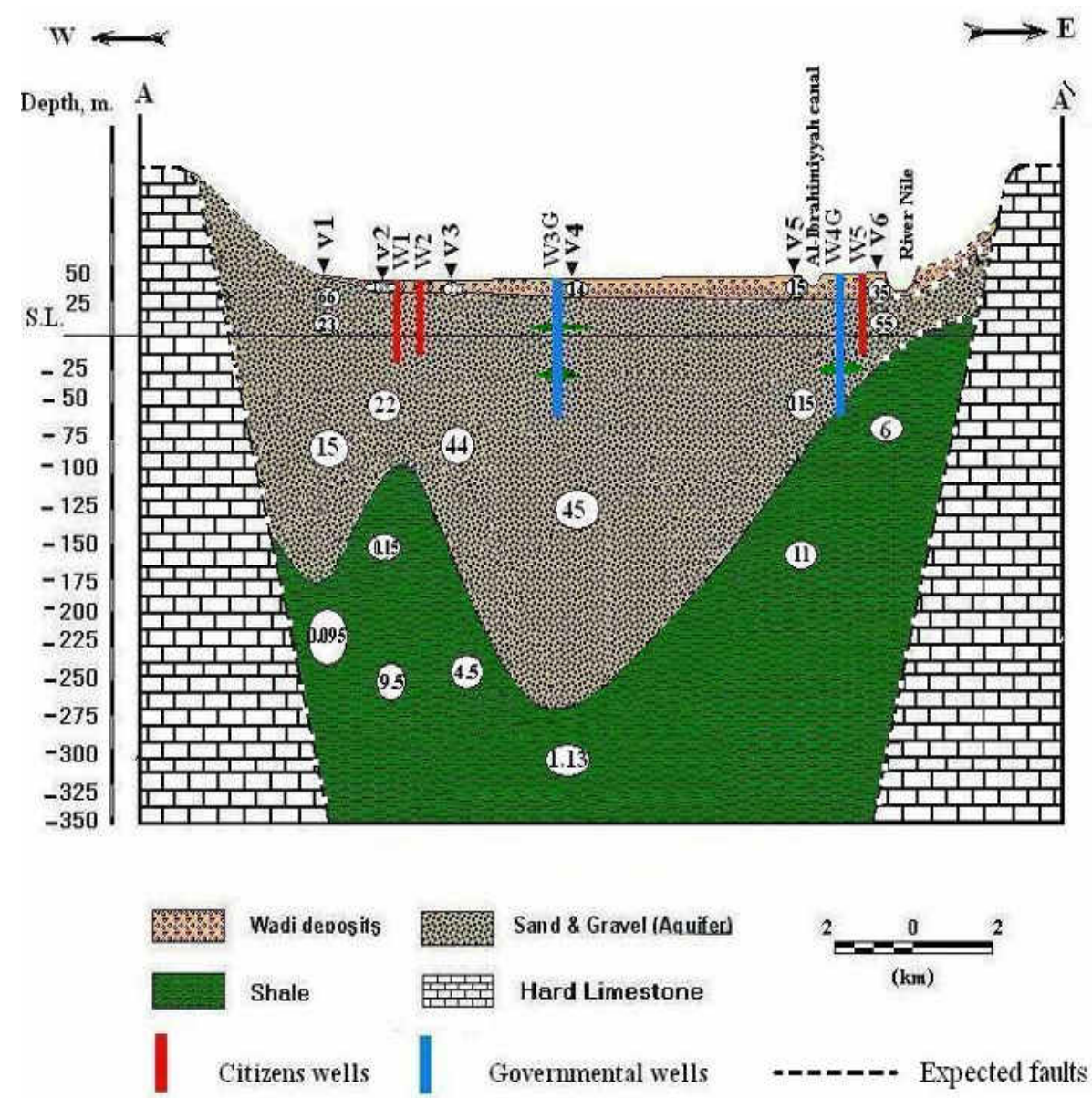

Fig. (7): Geoelectrical Cross section A-A' 


\section{Geoelectrical Cross section B-B'}

This section runs between El- Qusiya and Manfalut and located to the south of section A-A' by about 10 kilometers (Fig. 4). It is constructed from the results of soundings 7 , $8,9,10$ and 11 , and wells $6,7,8,9,10,11$ and 12 , with a length of about $13 \mathrm{~km}$. The valley is bounded on both sides by the Eocene limestone plateau. Three geoelectrical units could be recorded in this section (Fig. 8) and described as follows:

(a) A superficial geoelectric clay and silty clay cap with low resistivity values varying from 2 to $7.5 \mathrm{Ohm} . \mathrm{m}$. The thickness of this unit increases at the central part (about 13 m. near VES No. 9) and at the Eastern part (about $15 \mathrm{~m}$. in wells 11 and 12) and decreases towards East and West. At the site of VES No.7 it is covered by fine sands derived from the desert areas to the west.

(b) An intermediate geoelectric unit lies underlying the superficial unit. This unit is formed of sands, gravels and clay lenses with resistivity values ranging from $\sim 17$ Ohm.m. to about 120 Ohm.m., representing the main aquifer. This unit attains its maximum thickness at the site of VES No.10 and may reach about $250 \mathrm{~m}$. thick.

(c) A basal Pliocene clay unit can be differentiated at the base of the section forming the aquiclude of the Quaternary aquifer. This unit is characterized by its relatively low ohmic values $(1.6-9.9$ ohm.m). The old Nile erosion within the soft clay leads to observe differences in the level of the top of the Pliocene clay unit. It is clear that the recent course of the Nile is shifted to the east.

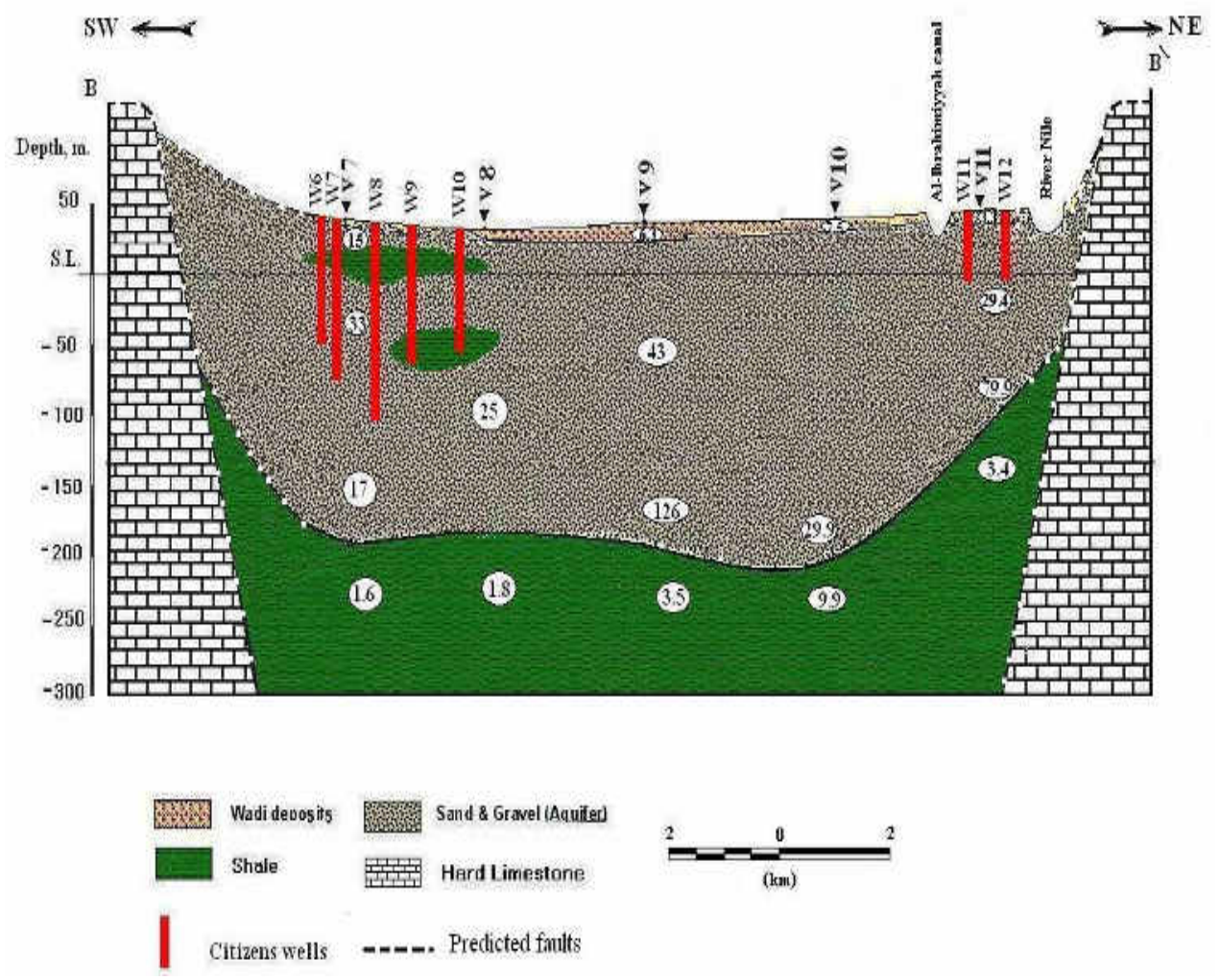

Fig. (8): Geoelectrical Cross section B-B' 


\section{Geoelectrical Cross section c-c'}

This section runs north Manfalut town (Fig. 4), and is based on soundings Nos. 12, 13, 14 and 15, and wells Nos. 13, 14, 15, 16 and 17. The direction of this section is SW$\mathrm{NE}$ with a width of about $11 \mathrm{~km}$. With the help of the wells, the section reflects the vertical variation in lithology and true resistivity values. Three geoelectrical units can be detected in this section (Fig. 9) and can be described as follows:

(a) A superficial geoelectric unit of clayey and silty deposits characterized by low electric resistivity values ( $\sim$ Ohm.m, -16 Ohm.m). This unit appears at the sites of VESes No.13, 14 and 15 . The thickness of this unit reaches its maximum value in well No. 17 and decreases gradually towards the East and West reaching $15 \mathrm{~m}$ thick. This unit represents the clay-silt cap of the Quaternary aquifer. The site of VES No.12 is characterized by another superficial high ohmic unit which is most probably due to existence of the fine sand derived from the desert areas to the west.

(b) A subsurface unit representing the Quaternary (Pleistocene) aquifer underlying the superficial unit. The formation is composed of sands, gravels with clay lenses with resistivity values ranging from 15 to $87 \mathrm{Ohm} . \mathrm{m}$. The maximum thickness of the aquifer is recorded near VES No.14, is about $300 \mathrm{~m}$. The thickness of the aquifer decreases towards East and West. The difference in resistivity is due to the lithologic variations.

(c) A basal zone characterized by very low ohmic values (2 Ohm.m - 4 Ohm.m.), which represents the Pliocene clay forming the aquiclude base of the Quaternary aquifer.

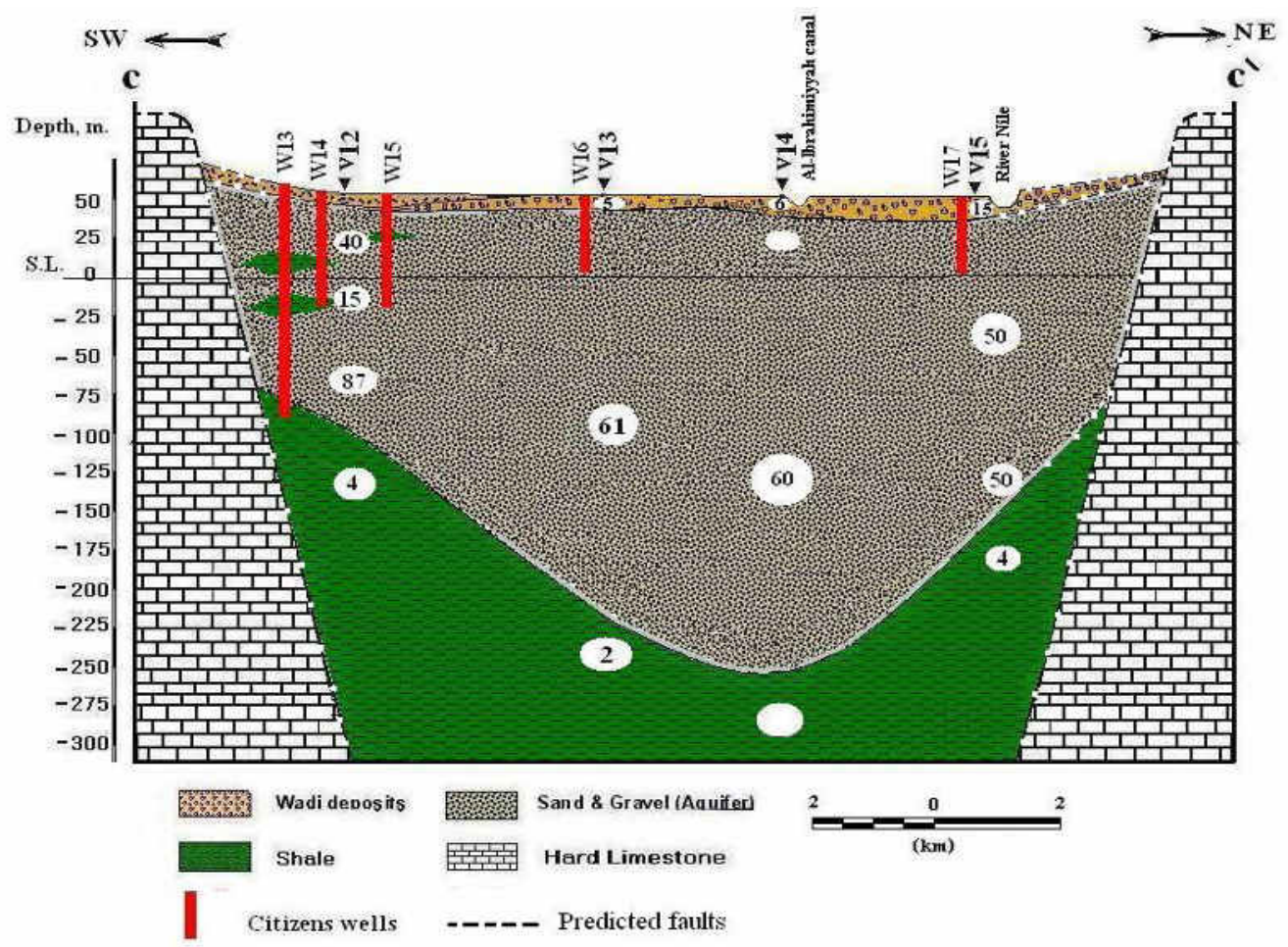

Fig. (9): Geoelectrical Cross section C - C' 


\section{Depth to the aquifer base contour map}

Based on the data of true depths deduced from the interpretation of the vertical electrical soundings a contour map of the aquifer base is constructed and shown in (Fig.10). The purpose of constructing this map is to show variations of the aquifer depth. The interpretation of this map indicates that the greater depth to the aquifer base is located at the central parts of the study area and decreases outward (i.e to the East and West). The maximum depth is recorded near Manfalut city, where it reaches $300 \mathrm{~m}$ from the ground surface. While the minimum depth is recorded at the East of ElQusiya city, where the depth ranging between 150 and $100 \mathrm{~m}$. below the ground surface.

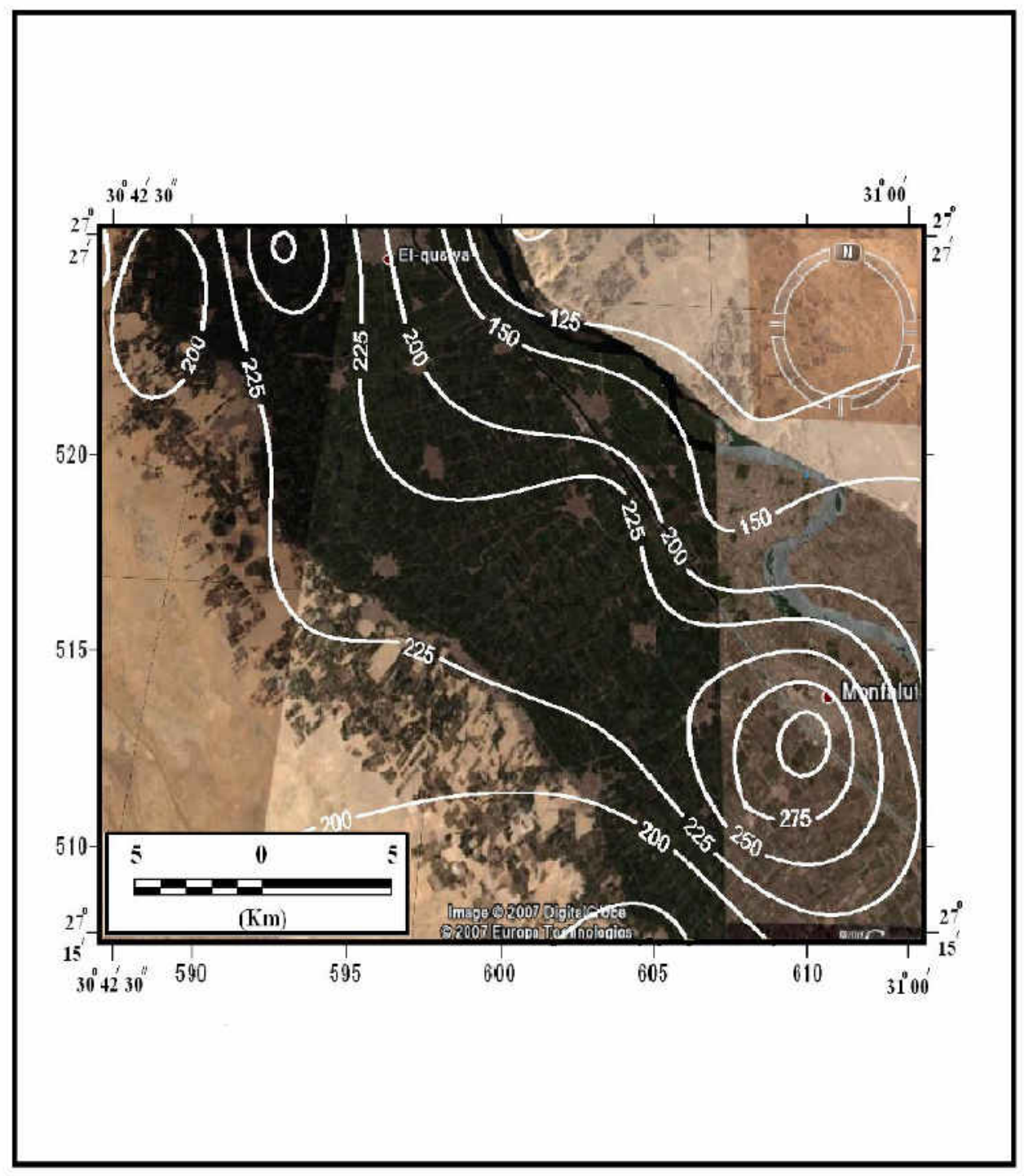

Fig. (10): The depth to the base of the Quaternary aquifer in the study area 


\section{Aquifer Isopach map}

This map (Fig.11) is constructed based on the data of true depths deduced from the interpretation of the vertical electrical soundings. The purpose of constructing this map is to show the thickness variations of the aquifer. The interpretation of this map indicates that the thickness of the quaternary aquifer in the study area ranges between 75 to $300 \mathrm{~m}$, in which the maximum thicknesses are detected around Manfalut and at the west of El-Qusiya, generally the central parts of the map have greater thickness than the outside parts and the Western parts than the Eastern also.

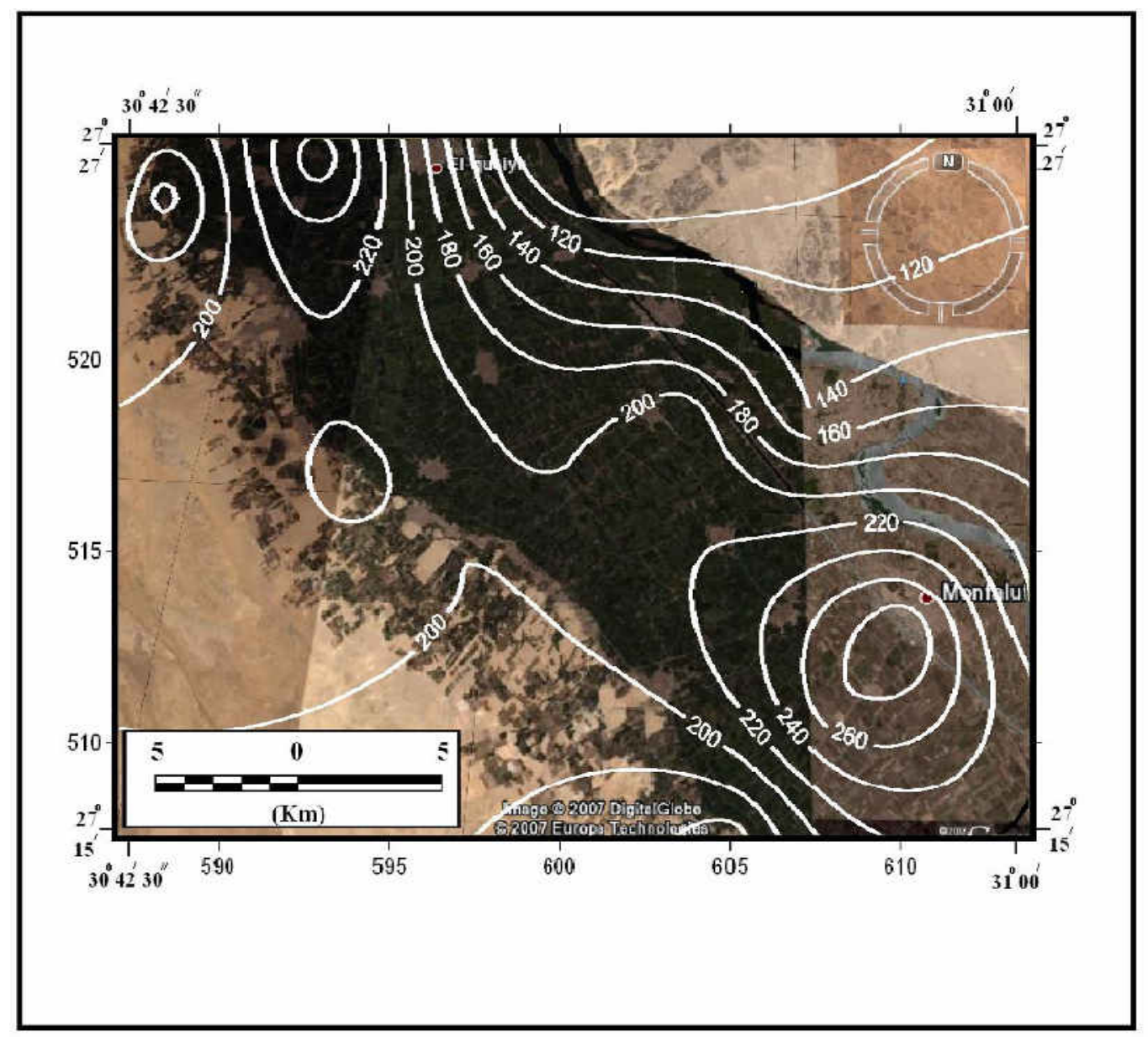

Fig. (11): Aquifer Isopach map

\section{CONCLUSIONS}

A comparison between drill holes and interpretation of electrical resistivity curves was used to give more information about groundwater bearing formation in the study area. In this study, three geoelectrical units could be detected.

The following points are concluded: 
1- A superficial thin unit of clayey and silty deposits characterized by low resistivity values (2-22 ohm.m.). The thickness of this unit reaches its maximum value near bore hole 5 to be $18 \mathrm{~m}$. This unit represents the clay-silt cap of the Quaternary aquifer.

2- A subsurface unit representing the Quaternary (Pleistocene) aquifer following the superficial unit. The formation is composed of sands, gravels with clay lenses with resistivity values ranging from 15 to $120 \mathrm{Ohm}$.m, and this refer to the change in lithology.

3- A basal zone characterized by its relatively low resistivity values (0.1-11 ohm.m.), which is considered to be equivalent to the Pliocene clay forming the basal aquiclude of the Quaternary aquifer.

4- Greater depth of aquifer base is located at the central part of the study area reaching about $300 \mathrm{~m}$ from the ground surface.

5- The region East of El-Qusiya city records the minimum depth of aquifer to the base ranging between 150 and $100 \mathrm{~m}$. below the ground surface.

6- The thickness of the Quaternary aquifer in the study area ranges between 75 to $300 \mathrm{~m}$, in which the maximum thicknesses are detected around Manfalut and at the west of El-Qusiya.

\section{REFERENCES}

1. Bishay. Y., " Biostratigraphic study of the Eocene in the Eastern Desert between Samalut and Assiut by the Large Formation", Third Arab Petrol. Cong., Alexandria, (1961).

2. Said, R., "The Geology of Egypt" Elsevier Pub. Amesterdam, New York, p. 377, (1962).

3. El-Gamili, M.M.H., "Geological and Geophysical Studies on Wadi El- Assiuty area, Eastern Desert, Egypt. M.Sc. Thesis, Dept. of Geo., Assiut University, (1964).

4. Shama, K. M., "The Geology of the Area Lying Between the Latitude of Manfalut and Deirut in the Eastern Side of the Nile Valley. M. Sc. Thesis, Dept. of Geology, Assiut University, (1972).

5. Bassiouni, M. A., Abdel Malik W. M., and Boukhary M., " Litho- and Biostratigraphy of Middle and Upper Eocene Rocks in the Minia- Beni-Suef reach of Nile Valley", Egypt. $6^{\text {th }}$ Afr. Micropleontol. Tunis, p. 101-113, (1974).

6. Youssef, M.M; Riad, S. and Mansour, H.H., "Surface and Subsurface Structural study study of the Area around Assiut ", Egypt, Bull. Fac. Sci., Assiut University, pp. 293-306, (1977).

7. Said, R., " The Geological Evaluation of the River Nile ", Springer Verlage, p. 138, (1981).

8. Nakhla, A., Kenneth, N.M. and Glen, T.P., "Aeromagnetic Evidence for a Deep Sedimentary Basin near Assiut, Egypt", Egyptian General Petroleum Corporation; pp. 244-259, (1986).

9. Continental Oil Company (CONOCO), "Geologic map of Egypt" (Scale 1: 500000), (1987). 
10. Rizkalla. I.R., "Interpretation of Aero-magnetic Data around Assiut Area, Eastern Desert", Egypt, E.G.S. Proc. of the $7^{\text {th }}$ Ann. Meet., March 1989, pp. 6576.

11. Said, R., "The Geology of Egypt", A. A. Balkeme. Rotterdam- Brootfield, p. 734, (1990).

12. Abd El-Monaim, A, E., " Geoelectrical and hydrogeologic studies on the Quaternary aquifer in the Nile Valley in Assiut and Sohag governorates, Egypt", ph.D. Thesis, Dept. of Geophysics, Faculty of Science, Ain shams University, Egypt, (1994).

13. Eman, M. M., "Groundwater Resources Evaluation of Assiut Governorate" , Ph.D. Thesis, Dept. of Geophysics, Faculty of Science, Assiut University, Egypt, (2004).

14. El Tahlawi, M. R, Farrag A. A and Ahmed S. S, "Groundwater of Egypt: "'an environmental overview', Springer-Verlag (2007).

15. Loke, M.H., " 1-D Resistivity,(RES1D) Program for Inversion and Forward Modeling

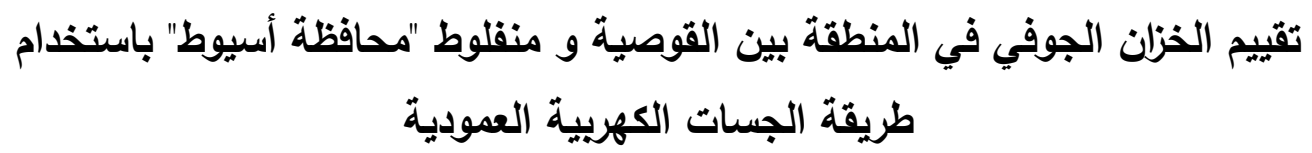

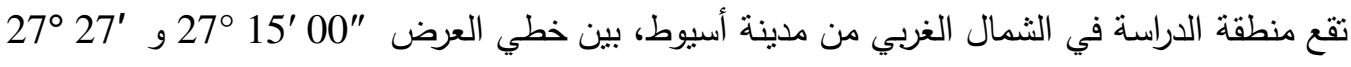
"00 شمالا ، وخطي الطول "30 '42 30 و '00 31³ شرقا ، وتغطي مساحة قدرها حوالي 330 كيلومتر مربع من وادي النيل. تم عمل 15 جسة كهربية في منطقة الدراسة، تم توزيعها على طول ثنلاث بروفيلات تخترق وادي النيل. تم تصميم تخلات قطاعات للتعرف على الثكل الهندسي والخصـائص الجيوكهربية للخزان الرباعي على طول البروفيلات نتيجة لتفسير منحنيات الجسات الكهربية وبالمقارنة مع المتاح من الآبار التي تم حفرها بالمنطقة. أمكن تحديد الثكل الهندسي للخزان الجوفي كذلك من خرائط العمق والسمك والذي تبين أنه غير منتظم ويتراوح سمكه بين 75 - 300 متر . حيث تم رصد أكبر سمك للخزان حول مدينة منفلوط وإلى الغرب من مدينة القوصية. 